\title{
Article \\ Life Cycle Assessment of Mortars Produced Partially Replacing Cement by Treated Mining Residues
}

\author{
Joana Almeida ${ }^{1,2, * \mathbb{C}}$, Paulina Faria ${ }^{1,3, * \mathbb{C}}$, Alexandra Branco Ribeiro ${ }^{2} \mathbb{D}$ and António Santos Silva $4 \mathbb{( \mathbb { C }}$ \\ 1 Department of Civil Engineering, NOVA School of Science and Technology, NOVA University Lisbon, \\ 2829-516 Caparica, Portugal \\ 2 CENSE-Center for Environmental and Sustainability Research, Department of Environmental Sciences and \\ Engineering, NOVA School of Science and Technology, NOVA University Lisbon, \\ 2829-516 Caparica, Portugal; abr@fct.unl.pt \\ 3 CERIS-Civil Engineering Research and Innovation for Sustainability, Instituto Superior Técnico, \\ University of Lisbon, 1049-001 Lisbon, Portugal \\ 4 Department of Materials, National Laboratory for Civil Engineering, 1700-066 Lisbon, Portugal; ssilva@lnec.pt \\ * Correspondence: js.almeida@campus.fct.unl.pt (J.A.); paulina.faria@fct.unl.pt (P.F.)
}

Citation: Almeida, J.; Faria, P.; Ribeiro, A.B.; Santos Silva, A. Life Cycle Assessment of Mortars Produced Partially Replacing Cement by Treated Mining Residues. Appl. Sci. 2021, 11, 7947. https://doi.org/ 10.3390/app11177947

Academic Editor: María

Ángeles Martín-Lara

Received: 3 August 2021

Accepted: 26 August 2021

Published: 27 August 2021

Publisher's Note: MDPI stays neutral with regard to jurisdictional claims in published maps and institutional affiliations.

Copyright: (c) 2021 by the authors. Licensee MDPI, Basel, Switzerland. This article is an open access article distributed under the terms and conditions of the Creative Commons Attribution (CC BY) license (https:// creativecommons.org/licenses/by/ $4.0 /)$.

\begin{abstract}
The use of secondary mining resources to replace conventional constituents in mortars production has proved the effectiveness to preserve the quality of mechanical, physical, and chemical properties. However, minimal research has been performed to quantify the environmental impacts of mortars with mining residues. In the present work, a life cycle assessment of 10 mortars was carried out. A reference mortar (100\% of cement binder) and mortars with cement substitutions in $10 \%, 25 \%$, and $50 \%$ by raw, electrodialytic treated, and electrodialytic plus thermal treated mining residues were analysed. The impacts were studied in six environmental categories: (1) abiotic depletion; (2) global warming; (3) ozone depletion; (4) photochemical ozone creation; (5) acidification; and (6) eutrophication potentials. The results demonstrated that mortars formulated with raw mining residues may decrease the environmental impacts, namely in global warming potential $(55.1 \mathrm{~kg}$ $\mathrm{CO}_{2}$ eq./t modified mortar). Considering the treatments applied to mining residues, the major mitigations were reported in photochemical ozone creation (-99\%), ozone depletion ( -76 to $-98 \%)$, and acidification potential ( -90 to $-94 \%$ ), mainly due to the disposal impacts avoided in comparison to the reference mortar. Analysing all mortars' constituents and their management options, products with electrodialytic treated mining residues showed higher influence in ozone depletion (18 to 52\%). Coupling a thermal procedure, mining residues contributed for $99 \%$ of the abiotic depletion potential of mortars.
\end{abstract}

Keywords: life cycle assessment; environmental impact; mortar; secondary mining resources; electrodialytic technology; thermal treatment

\section{Introduction}

In 2020, the release of greenhouse gases from building operations achieved $10 \mathrm{Gt} \mathrm{CO}_{2}$, being the highest level ever reported. Together with manufacturing, transportation and construction materials' uses, this represents $38 \%$ of global energy-related $\mathrm{CO}_{2}$ emissions [1].

Climate change and rapid urbanisation with growing population have prompted an emerging interest on construction industries to include more sustainable practices. To accomplish a net-zero carbon building stock in 2050 [2], direct and indirect building $\mathrm{CO}_{2}$ release needs to be reduced by an average of 55\% [3].

Furthermore, the emissions from the production of construction materials, and the construction itself, are mainly driven by cement and steel manufacturing. Their growth in use is the main contributor to buildings embodied carbon emissions. Around $50 \%$ of the cement demand comes from the construction sector, being imperative to reduce its use and replace cement by materials with lower embodied carbon [1]. 
The growing conscientiousness of mining residues impacts have empowered the study of feasible reuse options to reduce waste disposal, concerning a circular economy perspective and the Sustainable Development Goals [4]. Mining activities have reported high amounts of rejected fractions for hundreds of years, as a result of concentrate production. The accumulation of mining residues overtime, in open air impoundments, have led to an intense environmental degradation [5]. The contamination risks for the involved communities are a consequence of the emissions from chemical processes during concentrate production. Nitrogen and cyanide substances may reach aquatic systems, contributing to eutrophication and loss of biodiversity in water streams [6]. Sulfide minerals may contain harmful metals and metalloids, that could promote the formation of acids when in contact with water and oxygen, intensifying acidification phenomena [7]. On the other hand, fines and other particles may be released by the wind, increasing the cross contamination in the region [8].

To tackle climate change issues, the reuse of mining residues in construction products have been studied [9]. Mining resources were applied in geopolymers [10], innovative alkali-based materials for road pavement applications [11], red clay bricks [12], and lightweight construction products [13], with eco-efficient gains in mechanical strength, thermal stability, chemical and fire resistance, and costs [14]. In particular, the use of mining residues in mortars may improve their chemical and structural stability, although some research works reported low replacement cement percentages (e.g., 5\%) as effective for materials' requirements [15].

In this sense, the continuous optimization of secondary resources reuse to achieve a higher replacing rate of the virgin material in construction products manufacture, is also important.

The electrodialtytic (ED) process is a long-proven technology to remove substances of environmental concern from matrices, as well as to overcome raw materials' shortage and to contribute towards clean energy transition [16]. The ED process is based on the use of a direct low-level current intensity, in pairs of inert electrodes, that promotes the transport of contaminants by electromigration, electroosmosis, and electrophoresis mechanisms [17].

In comparison to metakaolin production and effect [18], the thermal treatment is also regarded as a strategy to take advantage of amorphous silica and/or alumina from fine secondary materials, conferring them pozzolanic properties whilst increasing the durability proprieties of final products [19].

Both ED and thermal treatments were applied to mining residues, and the treated material was used to replace cement in mortars production. The mortars produced with treated mining residues demonstrated positive achievements, and comprised the requirements needed for rendering, plastering, joint repointing, bedding masonry, or screed uses [20]. However, minimal research has been conducted to environmentally support the reuse of secondary resources in the roll out of sustainable cementitious construction products [21].

The life cycle assessment (LCA) has emerged as an important decision-making support tool in the construction industry [22]. This analysis technique provides an overview on the potential environmental impacts during a product/service life cycle. The LCA methodology is defined in ISO 14040 [23] and ISO 14044+A1 [24], and should be structured as follows: (1) goal definition and scope; (2) inventory appraisal; (3) impacts evaluation; and (4) interpretation [21]. The LCA provides an estimation of cumulative impacts that can also be used to quantify the embodied energy of products, considering environmental categories defined in EN 15804+A2 [25]. The inventory is the core of the LCA and, for this reason, reliable data from environmental product declarations (EPD), peer-reviewed scientific research works, in-site quantifications, and international databases should be preferentially used [26].

The built environment involves significant pressures on global resources. In this sense, the need to develop LCA methods, that critically appraise data on products environmental burdens to leverage new business opportunities, are a top priority. The present work aims 
at determining the environmental impacts that result from the incorporation of non-treated and treated mining residues, in different proportions, for cement-based mortar production. Those mortars were previously tested [20,27], presenting suitable properties for several current applications. The environmental impacts estimated and determined, based on six environmental categories, were analysed in terms of: (1) mitigation potential from mining residues uses, comparing to traditional mortar production with cement, (2) contribution of mining residues management scenarios (direct disposal, ED process and ED plus thermal treatment) in mortar manufacture, and (3) contribution of all the mortar components and respective management scenarios for the mortar lifecycle.

\section{Materials and Methods}

\subsection{Materials}

The mortars analysed in the present work were produced with mining residues from the Panasqueira mine (located in Covilhã, Portugal) and a Portuguese cement CEM II/B-L 32.5 classified according EN 197-1 [28]. A river siliceous sand was applied as aggregate, with similar proprieties to the CEN reference sand [29], and tap water was used to hydrate the formulation.

Mortar samples were produced in triplicate replacing $10 \%, 25 \%$, and $50 \%$ (wt $\%$ ) of the original cement content by mining residues under different conditions: raw, ED treated [27], and ED plus thermal treated [20]. A reference (REF) mortar was also included to compare the environmental impacts of the mortars with mining residues. The mortars analysed and their compositions are summarized in Table 1.

Table 1. Composition of the cement-based mortars analysed (adapted from [20,27]).

\begin{tabular}{|c|c|c|c|c|}
\hline \multirow[b]{2}{*}{$\begin{array}{l}\text { Mortar } \\
\text { Code }\end{array}$} & \multirow[b]{2}{*}{ Binder Composition } & \multicolumn{3}{|c|}{ Weight Proportion } \\
\hline & & $\begin{array}{c}\text { Binder } \\
\text { (Cement + Mining } \\
\text { Residues) }\end{array}$ & Sand & Water \\
\hline REF & $100 \%$ cement & \multirow{10}{*}{1} & 4.6 & \multirow{10}{*}{0.8} \\
\hline M10 & $10 \%$ raw mining residues $+90 \%$ cement & & 4.7 & \\
\hline M25 & $25 \%$ raw mining residues $+75 \%$ cement & & 4.8 & \\
\hline M50 & $50 \%$ raw mining residues $+50 \%$ cement & & 5.0 & \\
\hline ME10 & $10 \%$ ED mining residues $+90 \%$ cement & & 4.6 & \\
\hline ME25 & $25 \%$ ED mining residues $+75 \%$ cement & & 4.7 & \\
\hline ME50 & $50 \%$ ED mining residues $+50 \%$ cement & & 4.7 & \\
\hline MET10 & $\begin{array}{l}10 \% \mathrm{ED}+\mathrm{TT} \text { mining residues } \\
+90 \% \text { cement }\end{array}$ & & 4.6 & \\
\hline MET25 & $\begin{array}{l}25 \% \mathrm{ED}+\mathrm{TT} \text { mining residues } \\
+75 \% \text { cement }\end{array}$ & & 4.6 & \\
\hline MET50 & $\begin{array}{l}50 \% \text { ED + TT mining residues } \\
+50 \% \text { cement }\end{array}$ & & 4.6 & \\
\hline
\end{tabular}

\subsection{Scope Definition and LCA Boundaries}

The LCA of mortars was performed based on ISO 14040 [23] and ISO 14044+A1 [24]. Herein, the environmental sustainability of mortars was quantified at the product stage. Thus, the impacts of raw materials extraction and processing, and the mining residues management scenarios were analysed as presented in Figure 1. The declared unit defined for the present study was $1 \mathrm{t}$ of mortars. 


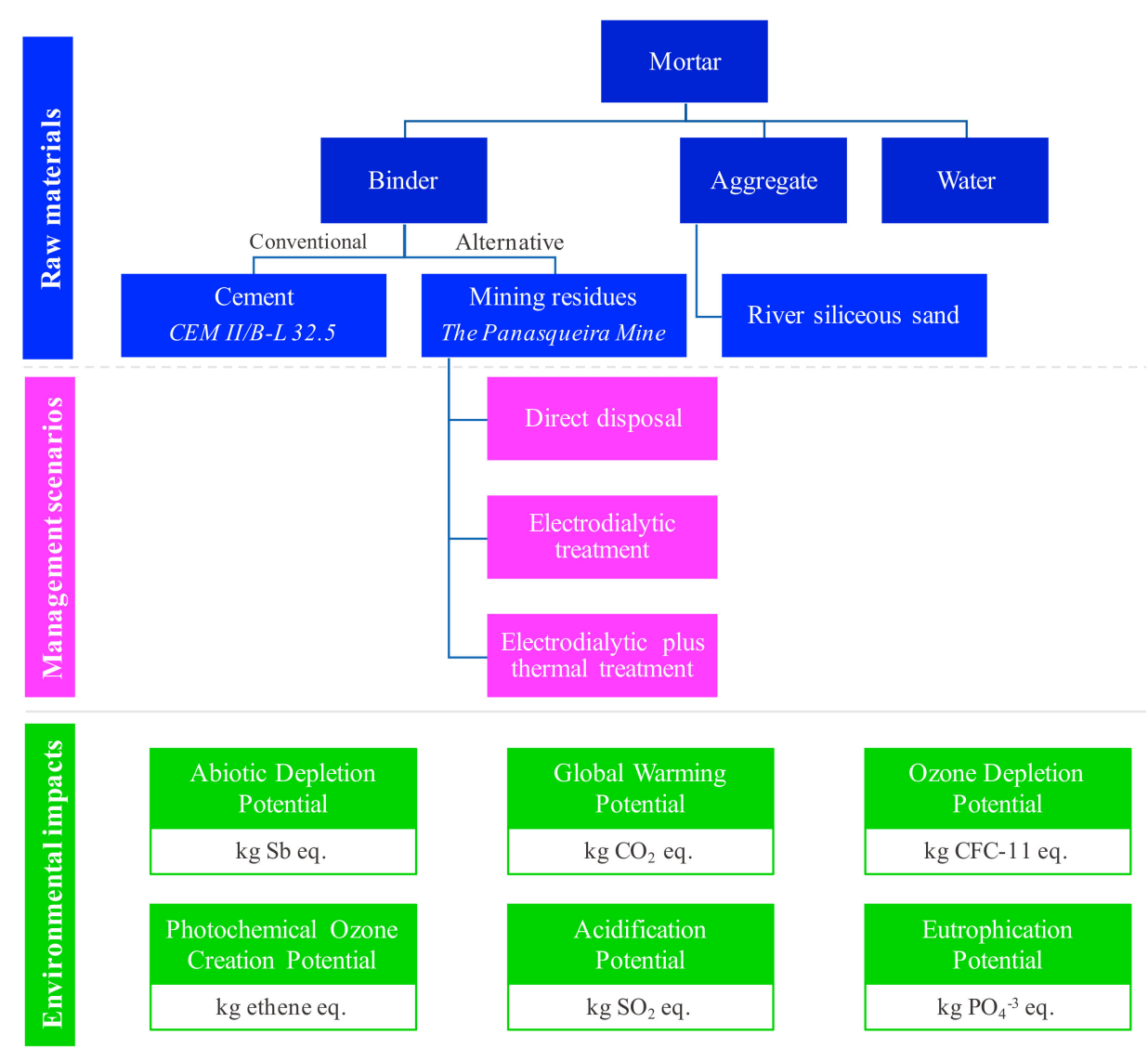

Figure 1. Flowchart of the elements included in the LCA of mortars, and the environmental impact categories analysed.

The environmental burdens were assessed through the analysis of six impact categories, based on EN 15804+A2 [25]: Abiotic depletion potential (ADP), global warming potential (GWP), ozone depletion potential (ODP), photochemical ozone creation potential $(\mathrm{POCP})$, acidification potential (AP), and eutrophication potential (EP). The analysis was performed based on the CML (Centrum voor Milieukunde Leiden) methodology, developed by the Institute of Environmental Sciences from Leiden University, the Netherlands [30].

\subsection{Data Collection}

The data used to shape the LCA of the raw materials involved was collected from peerreviewed scientific research works [7,26,31-34]. To determine the impact of the mortars with mining residues in the environmental categories studied, the composition of the mortars produced in previous works was considered (Table 1). The environmental impacts of $1 \mathrm{~kg}$ of cement, sand, water and mining residues, in the categories considered, are presented in Table 2, as well as the respective sources.

Regarding the management scenarios considered for mining residues, before their application in mortars, the data was equally collected from peer-reviewed scientific research works $[18,35]$. The environmental impacts considered from the disposal of $1 \mathrm{~kg}$ of mining residues, and also from the ED treatment of the same amount, are presented in Table 3. The impacts from the thermal treatment of mining residues were considered the same as the calcination of metakaolin, once both could be considered artificial pozzolans when subjected to identical thermal procedures [36]. 
Table 2. Environmental impacts of $1 \mathrm{~kg}$ of cement, sand, water, and mining residues.

\begin{tabular}{|c|c|c|c|c|c|c|c|}
\hline \multirow{3}{*}{$\begin{array}{c}\text { Mortar } \\
\text { Constituent }\end{array}$} & \multicolumn{6}{|c|}{ Environmental Impact Category } & \multirow{3}{*}{ Reference } \\
\hline & ADP & GWP & ODP & РОCP & AP & EP & \\
\hline & kg Sb eq. & $\mathrm{kg} \mathrm{CO}{ }_{2}$ eq. & kg CFC-11 eq. & kg ethene eq. & kg SO${ }_{2}$ eq. & $\mathrm{kg} \mathrm{PO}_{4}{ }^{3-}$ eq. & \\
\hline $\begin{array}{l}\text { Cement (CEM } \\
\text { II/B-L 32.5) }\end{array}$ & $1.10 \times 10^{-6}$ & $7.38 \times 10^{-1}$ & $1.10 \times 10^{-10}$ & $1.17 \times 10^{-4}$ & $1.21 \times 10^{-3}$ & $1.74 \times 10^{-4}$ & [26] \\
\hline Sand & $7.31 \times 10^{-11}$ & $2.46 \times 10^{-3}$ & $3.83 \times 10^{-10}$ & $1.08 \times 10^{-6}$ & $1.90 \times 10^{-5}$ & $2.03 \times 10^{-6}$ & [26] \\
\hline Water & $1.57 \times 10^{-11}$ & $1.33 \times 10^{-4}$ & $5.93 \times 10^{-12}$ & $3.87 \times 10^{-8}$ & $9.70 \times 10^{-7}$ & $4.99 \times 10^{-8}$ & [31] \\
\hline $\begin{array}{l}\text { Mining } \\
\text { residues a }\end{array}$ & $1.02 \times 10^{-5}$ & $4.75 \times 10^{-3}$ & $7.54 \times 10^{-10}$ & $4.24 \times 10^{-5}$ & $2.26 \times 10^{-5}$ & $1.06 \times 10^{-4}$ & {$[7,32-34]$} \\
\hline
\end{tabular}

ADP—Abiotic Depletion Potential; GWP—Global Warming Potential; ODP—Ozone depletion Potential; POCP—Photochemical Ozone Creation Potential; AP-Acidification Potential; and EP-Eutrophication Potential. ${ }^{\text {a }}$ Mining residues impacts were determined based on the production of $1 \mathrm{~kg}$ of concentrate at the mine. The impacts reported for ADP [32], and for the remaining impact categories analysed [33] were estimated per $\mathrm{kg}$ of mining residues produced, assuming that $1 \mathrm{~kg}$ of concentrate generates $442 \mathrm{~kg}$ of mining residues (ore grade $=0.3 \%$ $\mathrm{WO}_{3}[7]$ and concentrate grade $\left.=75 \% \mathrm{WO}_{3}[34]\right)$.

Table 3. Environmental impacts of the direct disposal, the electrodialytic treatment, and the thermal treatment of $1 \mathrm{~kg}$ of mining residues.

\begin{tabular}{|c|c|c|c|c|c|c|c|}
\hline \multirow{3}{*}{$\begin{array}{c}\text { Mining } \\
\text { Residues } \\
\text { Management }\end{array}$} & \multicolumn{6}{|c|}{ Environmental Impact Category } & \multirow{3}{*}{ Reference } \\
\hline & ADP & GWP & ODP & РОСР & AP & EP & \\
\hline & kg Sb eq. & $\mathrm{kg} \mathrm{CO} 2$ eq. & kg CFC-11 eq. & kg ethene eq. & $\mathrm{kg} \mathrm{SO} \mathrm{S}_{2}$ eq. & $\mathrm{kg} \mathrm{PO}_{4}{ }^{3-}$ eq. & \\
\hline Direct disposal & $3.35 \times 10^{-9 a}$ & $6.90 \times 10^{-1}$ & $9.80 \times 10^{-8}$ & $1.60 \times 10^{-2}$ & $1.20 \times 10^{-2}$ & $1.10 \times 10^{-4}$ & [35] \\
\hline $\begin{array}{l}\text { Electrodialytic } \\
\text { treatment }\end{array}$ & $2.92 \times 10^{-10 a}$ & $7.00 \times 10^{-2}$ & $4.10 \times 10^{-9}$ & $1.50 \times 10^{-4}$ & $2.80 \times 10^{-4}$ & $1.40 \times 10^{-5}$ & [35] \\
\hline $\begin{array}{l}\text { Thermal } \\
\text { treatment }^{b}\end{array}$ & $3.39 \times 10^{-3}$ & $4.21 \times 10^{-1}$ & $3.98 \times 10^{-8}$ & $5.20 \times 10^{-5}$ & $1.03 \times 10^{-3}$ & $6.47 \times 10^{-5}$ & [18] \\
\hline
\end{tabular}

ADP-Abiotic Depletion Potential; GWP—Global Warming Potential; ODP—Ozone depletion Potential; POCP—Photochemical Ozone Creation Potential; AP-Acidification Potential; and EP-Eutrophication Potential. a ADP data was converted from $\mathrm{kg}$ Fe eq. [35] to kg Sb eq. based on reference [37] data. A conversion factor of $1.17 \times 10^{7}$ was applied. ${ }^{b}$ The impacts reported from the thermal treatment of metakaolin were assumed as the same of mining residues due to the process similarities (e.g., considering thermal treatment up to $750{ }^{\circ} \mathrm{C}$ ).

\section{Results and Discussion}

\subsection{Impacts of Raw Materials in Mortar Manufacture}

During mortar production, there are several high energy consuming phases in regard to raw materials acquisition. In this context, the environmental impacts of using conventional materials, as cement, or raw mining residues in mortar manufacture was determined for $1 \mathrm{t}$ of mortars. The environmental pressures based on the typology of the binder used (cement and residue) as function of their content, in each category, are presented in Table 4.

Table 4. Environmental impacts from the production of $1 \mathrm{t}$ of mortars with cement and raw mining residues as binder constituents.

\begin{tabular}{|c|c|c|c|c|c|c|c|}
\hline \multirow{3}{*}{ Mortar } & \multirow{3}{*}{$\begin{array}{c}\text { Weight of } \\
\text { Cement } \\
\text { Replaced (\%) }\end{array}$} & \multicolumn{6}{|c|}{ Environmental Impact Category } \\
\hline & & ADP & GWP & ODP & POCP & AP & EP \\
\hline & & kg Sb eq. & $\mathrm{kg} \mathrm{CO} 2$ eq. & kg CFC-11 eq. & kg ethene eq. & kg SO${ }_{2}$ eq. & $\mathrm{kg} \mathrm{PO}_{4}{ }^{3-}$ eq. \\
\hline REF & 0 & $1.58 \times 10^{-4}$ & $1.08 \times 10^{2}$ & $2.72 \times 10^{-7}$ & $1.76 \times 10^{-2}$ & $1.87 \times 10^{-1}$ & $2.64 \times 10^{-2}$ \\
\hline M10 & 10 & $2.67 \times 10^{-4}$ & $9.73 \times 10^{1}$ & $2.79 \times 10^{-7}$ & $1.64 \times 10^{-2}$ & $1.70 \times 10^{-1}$ & $2.52 \times 10^{-2}$ \\
\hline M25 & 25 & $4.30 \times 10^{-4}$ & $8.15 \times 10^{1}$ & $2.91 \times 10^{-7}$ & $1.46 \times 10^{-2}$ & $1.44 \times 10^{-1}$ & $2.34 \times 10^{-2}$ \\
\hline M50 & 50 & $7.03 \times 10^{-4}$ & $5.51 \times 10^{1}$ & $3.10 \times 10^{-7}$ & $1.17 \times 10^{-2}$ & $1.01 \times 10^{-1}$ & $2.03 \times 10^{-2}$ \\
\hline
\end{tabular}

ADP—Abiotic Depletion Potential; GWP—Global Warming Potential; ODP—Ozone depletion Potential; POCP—Photochemical Ozone Creation Potential; AP_Acidification Potential; and EP-Eutrophication Potential. 
The major impacts that come from raw materials exploration and uses are reported in the GWP category. The GWP is based on the quantity of greenhouse gases released to the atmosphere, namely $\mathrm{CO}_{2}$ (that is dominant), methane $\left(\mathrm{CH}_{4}\right)$ and nitrous oxide $\left(\mathrm{N}_{2} \mathrm{O}\right)$. Thus, GWP means the total climate change impact of all the greenhouse gases caused by an item as function of the amount of $\mathrm{CO}_{2}$ that would have the same impact over a 100-year period [38].

From the production of $1 \mathrm{t}$ of mortars, $1.08 \times 10^{2} \mathrm{~kg} \mathrm{CO}_{2}$ eq. are released by the REF, followed by M10, M25, and M50. The highest the mining residues incorporation as binder, the lowest the GWP. When $50 \%$ of cement was replaced by secondary mining resources (M50), a decrease of $49 \%$ in GWP was achieved (55.1 $\mathrm{kg} \mathrm{CO}_{2}$ eq.)

Zajac et al. [39] reported the same trend, where $\mathrm{CO}_{2}$ emissions depend on the cement composition, and also on the level of fineness of the components. Since the emissions associated to the cement clinker are significantly higher than for other materials, the modification of the binder composition results in a significant reduction of the GWP [39].

The EP, POCP, and AP were lower than the REF, in sequence, when mining residues were used to replace cement at 50\% (less $23 \%, 34 \%$, and $46 \%$, respectively).

The EP gives an overview on nutritional elements presence in aquatic systems, namely nitrogen and phosphorus. The excessive concentration of these compounds decreases the oxygen available in water bodies and, consequently, water quality. This results in increased primary productivity and phytoplankton proliferation, where some species may present toxic risks [40].

Mines are often reported as a source of nutrients, namely regarding nitrogen that is used in the concentrate process for $\mathrm{pH}$ regulating, acid washing, or lixiviant agent [41]. In this way, significant decrease in EP is not expected, as it is foreseen in other environmental categories. The M50 mortar presented the lowest EP $\left(2.03 \times 10^{-2} \mathrm{~kg} \mathrm{PO}_{4}{ }^{3-}\right.$ eq. $)$. On the other hand, the various gases occurring by the hydration process of cement may release $\mathrm{NH}_{4}{ }^{+}$(ammonium) to the environment [42], contributing to the impacts observed in the EP for the REF $\left(2.64 \times 10^{-2} \mathrm{~kg} \mathrm{PO}_{4}{ }^{3-}\right.$ eq. $)$. Although EP is quantified in phosphates $\left(\mathrm{PO}_{4}{ }^{3-}\right)$ equivalents, it is also possible to convert them in ammonia $\left(\mathrm{NH}_{3}\right)$ equivalents, considering that $1 \mathrm{~kg}$ of $\mathrm{NH}_{3}$ has the same EP of $0.35 \mathrm{~kg} \mathrm{PO}_{4}{ }^{3-}$ [43].

The POCP is a secondary air pollution, also known as smog. This effect is mainly caused by the reactions between sunlight and emissions from fossil fuel combustion, promoting the formation of other chemicals in the troposphere, as ozone and peroxides. This leads to an increase of the ground-level ozone concentration [44]. The POCP is mainly related to the technology involved in raw materials production. In particular, grinding contributes to approximately 50\% of the energy consumed from cement production [39]. This may contribute to the higher emissions from REF $\left(1.76 \times 10^{-2} \mathrm{~kg}\right.$ ethene eq. $)$ that affect POCP, in comparison to M10, M25, and M50 mortars (an average of $1.42 \times 10^{-2} \mathrm{~kg}$ ethene eq.)

The AP is also affected by the combustion of fossil fuels, from industrial equipment, such as nitrous and sulfide oxides. In the presence of water and oxygen, these substances may leach and present risks for the surrounding ecosystems [45]. The presence of sulfide minerals in mining residues composition [5] may contribute to the AP detected at higher incorporation ratios of mining residues in mortars $\left(\mathrm{M} 50=1.01 \times 10^{-1} \mathrm{~kg} \mathrm{SO}_{2}\right.$ eq.). However, the AP of using mining residues still have lower proportions than REF $\left(1.87 \times 10^{-1} \mathrm{~kg} \mathrm{SO}_{2}\right.$ eq.). The emissions from the combustion processes of the kilns in a cement industry may release $\mathrm{HCl}$ and $\mathrm{HF}$ [46], with repercussions in the AP.

Contrarily, mining residues demonstrated to have higher ODP (up to 2.5\%) and, more significant, ADP (above 41\%), in comparison to cement. The ODP is related to the ozone density decrease through the thinning of the stratospheric ozone layer, as a consequence of anthropogenic pollutants (e.g., halocarbons) [47]. Once more, the source of pollution associated to ODP is predominantly associated to the equipment involved in mining activities and cement production, being the differences between the two types of binders marginal (an average of approximately $3.0 \times 10^{-7} \mathrm{~kg} \mathrm{CFC-11} \mathrm{eq.} \mathrm{for} \mathrm{all} \mathrm{the} \mathrm{mortars).}$ 
The natural resources needed for raw materials production can be considered renewable (e.g., groundwater and wood) and nonrenewable (e.g., minerals and fossil fuels). The ADP refers to the exhaustion of nonrenewable resources and the resultant environmental impacts, being mainly affected by the rate of resources extraction [47]. In fact, the exploration of mine ores involves extremely high quantities of mining residues generation, due the low ore grades in comparison to the past [48]. Comparing to REF $\left(1.58 \times 10^{-4} \mathrm{~kg} \mathrm{Sb}\right.$ eq.), there are more wastage when the initial source is being explored, which explains the higher impacts observed in ADP for M10, M25, and M50 mortars (between $2.67 \times 10^{-4}$ and $7.03 \times 10^{-4} \mathrm{~kg} \mathrm{Sb}$ eq.).

\subsection{Impacts of Mining Residues Management Scenarios in Mortar Production}

Bearing in mind the potential of mining residues as a secondary source of raw materials with high economic potential and in risk of scarcity [49], the ED process was applied to mining residues as a way to contribute for circular economy targets [50]. Furthermore, the thermal treatment prospective for enhancing mining residues pozzolanic reactivity and improve durability properties, could enlarge the applicability of this material in construction products [19]. In this sense, mortars were produced with mining residues treated with the ED technology [27] and with ED plus thermal treatment [20]. To complement the technical analysis of the properties of the mortars produced with treated mining residues, the environmental impacts were determined and compared to the REF (Table 5). Three management scenarios were considered for the mining residues: direct disposal; ED treatment; ED plus thermal treatment. Once REF did not include mining residues, it is assumed that the amount of cement used is the same quantity of mining residues that are directly disposed at the mining site.

Table 5. Environmental impacts from the production of $1 \mathrm{t}$ of mortars with cement and treated mining residues as binder constituents.

\begin{tabular}{|c|c|c|c|c|c|c|c|c|}
\hline \multirow{3}{*}{ Mortar } & \multirow{3}{*}{$\begin{array}{l}\text { Weight of } \\
\text { Cement } \\
\text { Replaced (\%) }\end{array}$} & \multirow{3}{*}{$\begin{array}{l}\text { Management } \\
\text { of Mining } \\
\text { Residues }\end{array}$} & \multicolumn{6}{|c|}{ Environmental Impact Category } \\
\hline & & & ADP & GWP & ODP & РОCP & AP & EP \\
\hline & & & kg Sb eq. & kg CO 2 eq. & kg CFC-11 eq. & kg ethene eq. & kg SO${ }_{2}$ eq. & $\mathrm{kg} \mathrm{PO}_{4}{ }^{3-}$ eq. \\
\hline REF & 0 & Disposal & $1.59 \times 10^{-4}$ & $2.07 \times 10^{2}$ & $1.44 \times 10^{-5}$ & 2.32 & 1.91 & $4.22 \times 10^{-2}$ \\
\hline ME10 & 10 & ED & $1.43 \times 10^{-4}$ & $9.83 \times 10^{1}$ & $3.28 \times 10^{-7}$ & $1.80 \times 10^{-2}$ & $1.73 \times 10^{-1}$ & $2.41 \times 10^{-2}$ \\
\hline ME25 & 25 & ED & $1.19 \times 10^{-4}$ & $8.38 \times 10^{1}$ & $4.11 \times 10^{-7}$ & $1.86 \times 10^{-2}$ & $1.53 \times 10^{-1}$ & $2.06 \times 10^{-2}$ \\
\hline ME50 & 50 & ED & $7.92 \times 10^{-5}$ & $5.97 \times 10^{1}$ & $5.51 \times 10^{-7}$ & $1.96 \times 10^{-2}$ & $1.19 \times 10^{-1}$ & $1.49 \times 10^{-2}$ \\
\hline MET10 & 10 & $\mathrm{ED}+\mathrm{TT}$ & $4.99 \times 10^{-2}$ & $1.05 \times 10^{2}$ & $9.14 \times 10^{-7}$ & $1.89 \times 10^{-2}$ & $1.89 \times 10^{-1}$ & $2.51 \times 10^{-2}$ \\
\hline MET25 & 25 & $\mathrm{ED}+\mathrm{TT}$ & $1.26 \times 10^{-1}$ & $9.95 \times 10^{1}$ & $1.89 \times 10^{-6}$ & $2.08 \times 10^{-2}$ & $1.92 \times 10^{-1}$ & $2.31 \times 10^{-2}$ \\
\hline MET50 & 50 & $\mathrm{ED}+\mathrm{TT}$ & $2.51 \times 10^{-1}$ & $9.11 \times 10^{1}$ & $3.51 \times 10^{-6}$ & $2.41 \times 10^{-2}$ & $1.97 \times 10^{-1}$ & $1.97 \times 10^{-2}$ \\
\hline
\end{tabular}

ED—Electrodialytic treatment; TT—Thermal treatment; ADP—Abiotic Depletion Potential; GWP—Global Warming Potential; ODP—Ozone depletion Potential; POCP—Photochemical Ozone Creation Potential; AP—Acidification Potential; and EP—Eutrophication Potential.

Based on Table 5 data, the REF presented the higher impacts per $t$ of mortars in GWP $\left(2.07 \times 10^{2} \mathrm{~kg} \mathrm{CO} 2\right.$ eq.), ODP $\left(1.44 \times 10^{-5} \mathrm{~kg}\right.$ CFC-11 eq.), POCP $(2.32 \mathrm{~kg}$ ethene eq.), and $\mathrm{AP}\left(1.91 \mathrm{~kg} \mathrm{SO} \mathrm{eq}_{2}\right.$ eq). Furthermore, the management scenario selected for mining residues in the REF case (direct disposal), demonstrated higher GWP, ODP, POCP, and AP than the other options (Table 3). This augmented the overall environmental pressures from REF production.

The application of the ED technology showed positive achievements, once the lowest impacts were observed in all the categories analysed. In particular, ADP $\left(7.92 \times 10^{-5} \mathrm{~kg} \mathrm{Sb}\right.$ eq. $)$, GWP (59.7 kg CO 2 eq.), AP $\left(1.19 \times 10^{-1} \mathrm{~kg} \mathrm{SO}_{2}\right.$ eq. $)$, and $\mathrm{EP}\left(1.49 \times 10^{-2} \mathrm{~kg} \mathrm{PO}_{4}{ }^{3-}\right.$ eq. $)$ were strongly alleviated when $50 \%$ of ED mining residues were incorporated in mortars. The reuse of a rejected fraction that is commonly disposed as waste and the removal of harmful compounds, that have severe risks for the environmental, coupled with a sec- 
ondary recovery of raw materials, are the main benefits of using the ED technology. In addition, the land occupied by mining residues discharges is also reduced. These aspects overlap the energy consumed during the ED process.

The ODP and POCP were also lower than REF, albeit the impacts increased with ED mining residues incorporation increase in mortars. An impact intensification of $40 \%$ and $8 \%$ was observed for ODP and POCP, respectively, from ME10 (ODP $=3.28 \times 10^{-7} \mathrm{~kg}$ CFC-11 eq. and POCP $=1.80 \times 10^{-2} \mathrm{~kg}$ ethene eq.) to ME50 (ODP $=5.51 \times 10^{-7} \mathrm{~kg} \mathrm{CFC-11}$ eq. and $\mathrm{POCP}=1.96 \times 10^{-2} \mathrm{~kg}$ ethene eq.). During the ED treatment, the gases that could be formed due to the electrode reactions are commonly released to the atmosphere. The gases generated during the ED process depend on the matrix composition. For instance, chlorine gas could be generated at the anode in systems with high chloride contents [51]. This may have contributed to the impacts increase verified with more replacing content of cement by ED mining residues.

When mining residues were submitted to ED plus thermal treatment, an increase in the impacts was observed in comparison to ED mining residues. In fact, the energy consumed to heat the sample is the major contributor to the impact's intensification, as well as other VOC (volatile organic compounds) emitted from the calcination process [36]. For this reason, the impacts of MET10, MET25, and MET50 in ADP (from $4.99 \times 10^{-2}$ to $1.26 \times 10^{-1} \mathrm{~kg} \mathrm{Sb}$ eq.) and GWP (from 91.1 to $105 \mathrm{~kg} \mathrm{CO}_{2}$ eq.) were higher than ME10, ME25, and ME50. The need of more fossil fuels and, consequently, the higher $\mathrm{CO}_{2}$ released during the calcination affected both categories. Figure 2 presents the mitigation of the environmental burdens achieved when mortars were produced with treated mining residues, in relation to the REF baseline.

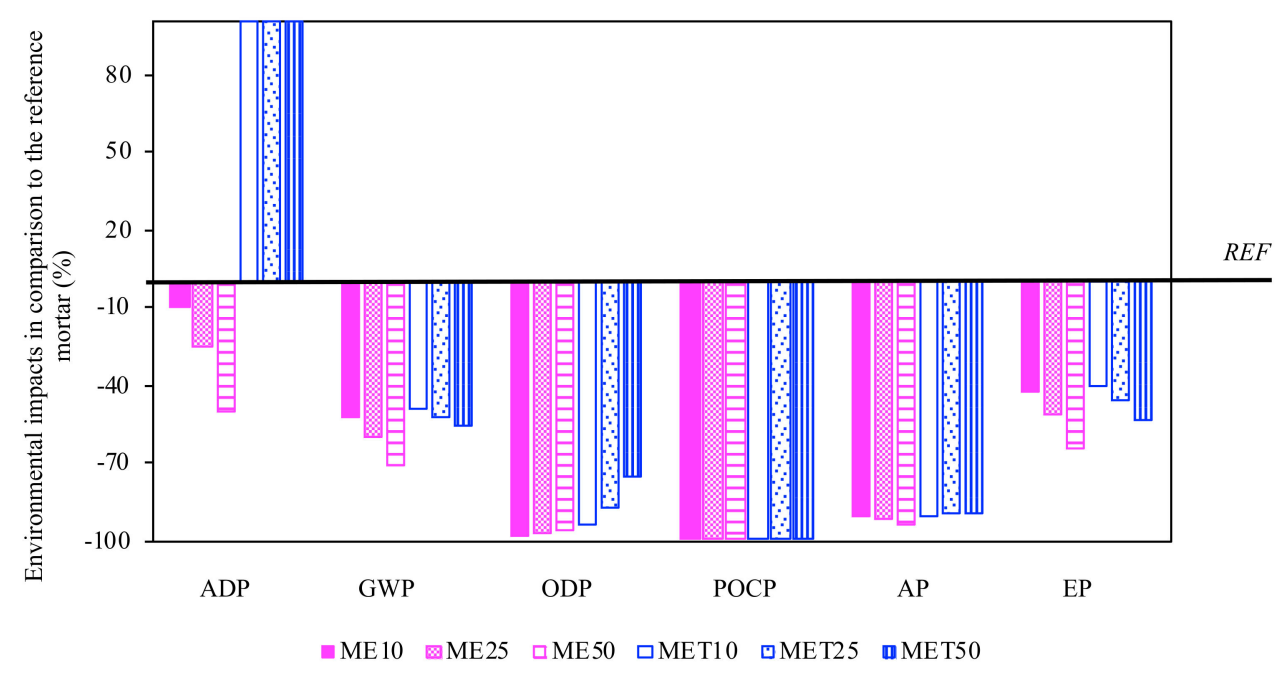

Figure 2. Environmental impacts mitigation of mortars produced with treated mining residues, compared to the reference mortar baseline. ADP-Abiotic Depletion Potential; GWP—Global Warming Potential; ODP - Ozone depletion Potential; POCP—Photochemical Ozone Creation Potential; AP-Acidification Potential; and EP_Eutrophication Potential.

Almost all the environmental pressures of mortars with treated mining residues reduced, namely in POCP $(-99 \%)$, ODP $(-76$ to $-98 \%)$, and AP (-90 to $-94 \%)$. This occurred due to the lower cement amount, that requires less energy and related emissions from cement production. Also, the disposal impacts of mining residues that are avoided, in comparison to the REF, promoted the decrease of environmental deterioration. High $\mathrm{CH}_{4}$ emissions are associated to waste disposal, that are 28 times more potent than $\mathrm{CO}_{2}$ [38].

Nevertheless, the ADP of MET10, MET25, and MET50 (from $4.99 \times 10^{-2}$ to $1.26 \times 10^{-1} \mathrm{~kg}$ $\mathrm{Sb}$ eq.) were higher than REF $\left(1.59 \times 10^{-4} \mathrm{~kg} \mathrm{Sb}\right.$ eq. $)$. Apart from the cement production and mining residues generation burdens, the fossil fuels needed for the thermal treatment augmented the exploration of more resources, highly impacting this category. 


\subsection{Impacts of Constituents and Management Scenarios in Mortars' Lifecycle}

Mortars are commonly composed by mineral binders, aggregates, and water [52]. In this study, only the binder was modified during mortar production, comparing with conventional manufacture. However, the impacts of mortars should gather all the involved elements in its assembly. In this sense, Figure 3 summed up the weight that mortars components and their respective management scenarios, may have in the environmental categories analysed (based on data from Tables A1-A6, in Appendix A).

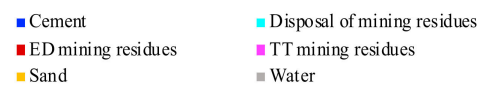

(A) Abiotic Depletion Potential

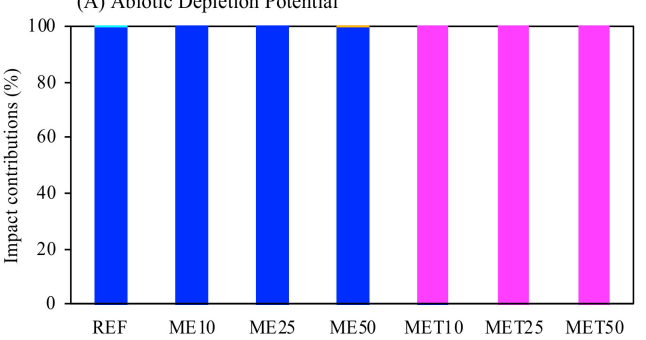

(C) Ozone Depletion Potential

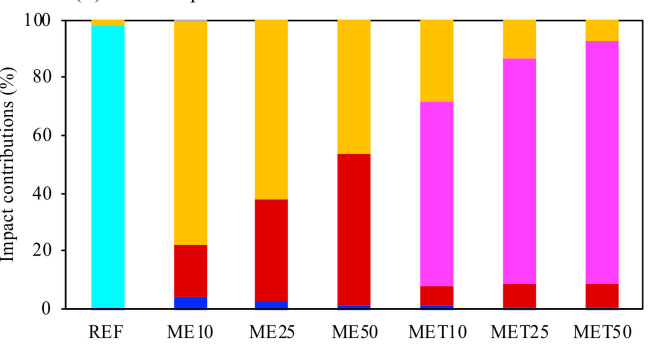

E) Acidification Potential

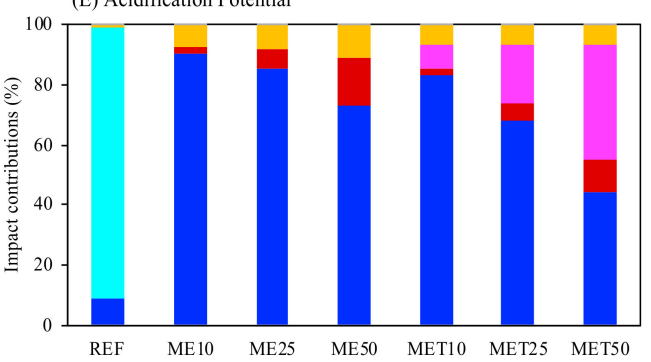

(B) Global Warming Potential

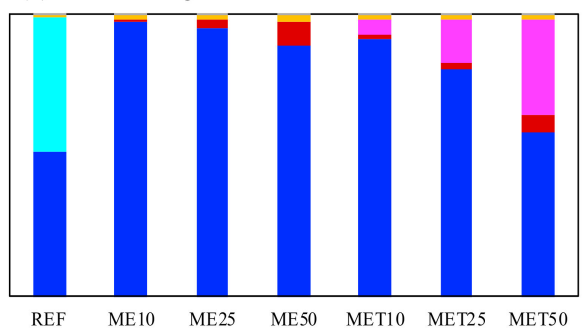

(D) Photochemical Ozone Creation Potential

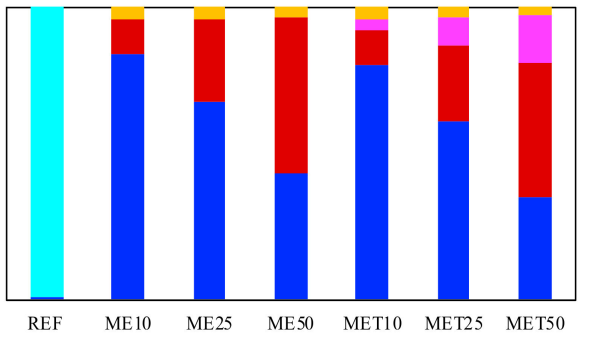

(F) Eutrophication Potential

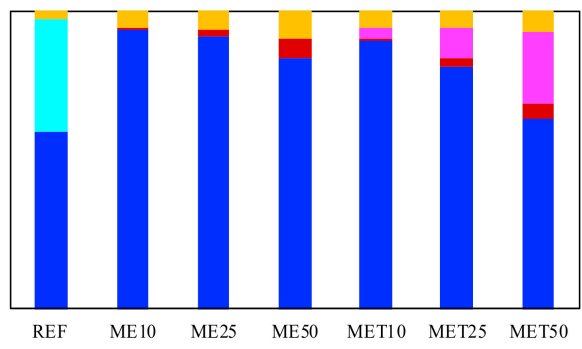

Figure 3. Contribution of mortars' constituents for the environmental impacts in the categories analysed: (A) Abiotic Depletion Potential; (B) Global Warming Potential; (C) Ozone depletion Potential; (D) Photochemical Ozone Creation Potential; (E) Acidification Potential; and (F) Eutrophication Potential.

The water used in mortar manufacture has no significant expression in the environmental categories analysed, when compared with the other components. However, it is important to notice that water is the most consumed substance on the planet. The rapid economic and population growth have increased water demand and limited water supplies, and better management measures to alleviate water scarcity are desired [53].

The aggregate fraction (sand) demonstrated higher weight in ODP, particularly in ME10 (78\%), ME25 (62\%), and ME50 (46\%). From the production of $1 \mathrm{t}$ of mortars, a total of $2.55 \times 10^{-7} \mathrm{~kg}$ CFC-11 eq. are released from sand exploration. (Table A3, in Appendix A). The extraction of alluvial material from river beds and sections present degradation risks, increasing the need to develop new strategies for the extraction quarries [54]. Raw silica sand could also be excavated from deposits in open-pit mines. However, sand shortage is also an important issue, constituting one of the greatest sustainability challenges of this 
century [55]. The exploitation of silica sand for industrial application implies the removal of gangue minerals from excavated topsoil, commonly carried out in a processing plant [56]. The equipment involved on sand exploitation justify the higher ODP, when compared to the other constituents processing methods.

The typology of the binder applied in mortars manufacture demonstrated different behaviors in mortars' overall impacts. The ED mining residues showed higher percentual representativity in POCP (53\%) and ODP (52\%), for ME50. Coupling the thermal treatment to mining residues contributed to $64-84 \%$ of the ODP in MET10, MET25, and MET50, and for almost $100 \%$ of the ADP. The disposal of mining residues, as a result of the reuse absence in REF, contributed to the majority of the ODP (98\%), POCP (99\%), and AP (90\%).

Concerning the conventional option, cement has a significant expression in ADP (almost 100\% for REF, ME10, ME25, and ME50), GWP (from REF $=51 \%$ to ME10 $=97 \%$ ), AP (from MET50 $=44 \%$ to ME10 $=90 \%$ ), and EP (from REF $=59 \%$ to ME10 $=94 \%$ ). Even when cement was replaced at $50 \%$ ratios, the impacts of mortars with treated mining residues incorporation were mainly due to the cement presence. Only the mining residues subjected to ED plus thermal treatment exceeded the cement impacts in the ADP.

\section{Conclusions}

The decarbonisation of the power sector and the implementation of materials' strategies will be important drivers towards a net zero carbon emissions in the construction industry. In particular, the incorporation of innovative circular materials and products, that can be recovered in closed-loop systems, could contribute to decrease the environmental burdens from cement uses in mortars. Although technological and commercial viable solutions exist, stronger policies and collaborations to accelerate scale up are crucial.

Aiming to provide a decision-making tool for future developments, while keeping up with the technological progress, this work presents a LCA methodology to quantify the sustainability of mortars produced with secondary mining resources partially replacing cement. Considering six environmental categories, $1 \mathrm{t}$ of 10 different mortars were analysed: a reference mortar (100\% of CEM II/B-L 32.5 as binder) and mortars with cement substitutions in $10 \%, 25 \%$, and $50 \%$ by raw, electrodialytic treated and electrodialytic plus thermal treated mining residues.

- Generally, mortars produced with mining residues presented an eco-friendlier behavior than the reference mortar. The use of mining residues as binder can avoid almost $50 \%$ of the GWP, meaning the release of $55.1 \mathrm{~kg} \mathrm{CO} 2$ eq. $/ \mathrm{t}$ modified mortar. The lower the cement content, the lower the energy involved in mortar production, namely due to the clinker formation that requires temperatures above $1000{ }^{\circ} \mathrm{C}$ and energy consuming milling.

- The adoption of mining residues management scenarios, before their reuse in mortars' manufacture, was assessed considering direct disposal, ED treatment and ED treatment coupled with a thermal procedure. Herein, the impacts of mortars were strongly alleviated in POCP ( $-99 \%)$, ODP ( -76 to $-98 \%$ ) and AP ( -90 to $-94 \%)$, comparing to the reference. The avoided mining residues discharges were key factor for these decreases, together with lower cement incorporation.

- The overall mortar lifecycle was performed considering all the mortar components and respective management scenarios. The aggregate fraction demonstrated higher impact weight in ODP (between 46 and 78\%), while the typology of the binder applied showed different environmental performances. ED mining residues showed higher representativity in POCP (53\%) and ODP (52\%), whereas ED plus thermal treated mining residues contributed to $64-84 \%$ of the POCP, and to almost $100 \%$ of the ADP.

- Cement has a significant expression in ADP (almost 100\%) and GWP (51-97\%). The impacts of mortars with treated mining residues are mainly caused by cement contents, even at higher replacement ratios. Nevertheless, fossil fuels needed for the thermal treatment of mining residues increased the resources required, promoting a higher ADP than cement. 
Furthermore, other stages not considered in the present work may influence the embodied energy of mortars, namely construction, use and end-of-life phases. The energy spend on grinding activities can differ from material to material, and according to industrial methods. Scaling up approaches and the increase of renewable energy in the grid will be important steps to decrease the impacts of fossil fuels consumption during the involved processes. The cost analysis of the mortars produced by partial replacement of cement with treated mining residues could also complement the life-cycle assessment. This step is relevant to evaluate the economic feasibility of the mortars in the current market and correlate data with the environmental benefits observed.

Author Contributions: Conceptualization, J.A.; Data curation, J.A.; Formal analysis, P.F., A.B.R. and A.S.S.; Funding acquisition, P.F. and A.B.R.; Methodology, J.A.; Project administration, P.F. and A.B.R.; Resources, P.F. and A.B.R.; Supervision, P.F., A.B.R., and A.S.S.; Validation, P.F., A.B.R., and A.S.S.; Writing-original draft, J.A.; Writing-review and editing, J.A., P.F., A.B.R., and A.S.S. All authors have read and agreed to the published version of the manuscript.

Funding: This work has received funding from the European Union's Horizon 2020 research and innovation program under the Marie Skłodowska-Curie grant agreement No. 778045. The authors acknowledge the Portuguese Foundation for Science and Technology (FCT) for the support given to CENSE and CERIS through the strategic projects UIDB/04085/2020 and UIDB/04625/2020, respectively, and for J. Almeida fellowship PD/BD/135170/2017 from the EcoCoRe (Eco-Construction and Rehabilitation) Doctoral program.

Institutional Review Board Statement: Not applicable.

Informed Consent Statement: Not applicable.

Conflicts of Interest: The authors declare no conflict of interest.

\section{Appendix A. (Supplementary Data)}

Table A1. Environmental impacts in the Abiotic Depletion Potential category, from the production of $1 \mathrm{t}$ of mortars with cement and treated mining residues as binder constituents.

\begin{tabular}{lccccc}
\hline \multirow{2}{*}{ Mortar } & Cement & $\begin{array}{c}\text { Disposal of } \\
\text { Mining Residues }\end{array}$ & $\begin{array}{c}\text { ED Mining } \\
\text { Residues }\end{array}$ & $\begin{array}{c}\text { TT Mining } \\
\text { Residues }\end{array}$ & Sand \\
\cline { 2 - 6 } & $1.58 \times 10^{-4}$ & $4.82 \times 10^{-7}$ & n.a. & n.a. & \\
REF & $1.43 \times 10^{-4}$ & n.a. & $4.08 \times 10^{-9}$ & n.a. & $1.59 \times 10^{-4}$ \\
ME10 & $1.19 \times 10^{-4}$ & n.a. & $1.02 \times 10^{-8}$ & n.a. & $4.87 \times 10^{-8}$ \\
ME25 & $7.92 \times 10^{-5}$ & n.a. & $2.04 \times 10^{-8}$ & n.a. & $1.74 \times 10^{-9}$ \\
ME50 & $1.43 \times 10^{-4}$ & n.a. & $4.28 \times 10^{-9}$ & $4.97 \times 10^{-2}$ & $7.92 \times 10^{-5}$ \\
MET10 & $1.19 \times 10^{-4}$ & n.a. & $1.08 \times 10^{-8}$ & $1.25 \times 10^{-1}$ & $4.99 \times 10^{-2}$ \\
MET25 & $7.92 \times 10^{-5}$ & n.a. & $2.16 \times 10^{-8}$ & $2.51 \times 10^{-1}$ & \\
MET50 & & & & \\
\hline
\end{tabular}

ED—Electrodialytic Treatment; TT—Thermal Treatment; ADP—Abiotic Depletion Potential; and n.a.—not applicable.

Table A2. Environmental impacts in the Global Warming Potential category, from the production of $1 \mathrm{t}$ of mortars with cement and treated mining residues as binder constituents.

\begin{tabular}{|c|c|c|c|c|c|c|c|}
\hline \multirow[b]{2}{*}{ Mortar } & \multicolumn{7}{|c|}{ GWP (kg CO $\mathrm{C}_{2}$ eq.) } \\
\hline & Cement & $\begin{array}{c}\text { Disposal of } \\
\text { Mining Residues }\end{array}$ & $\begin{array}{l}\text { ED Mining } \\
\text { Residues }\end{array}$ & $\begin{array}{l}\text { TT Mining } \\
\text { Residues }\end{array}$ & Sand & Water & Total \\
\hline REF & $1.06 \times 10^{2}$ & $9.93 \times 10^{1}$ & n.a. & n.a. & & & $2.07 \times 10^{2}$ \\
\hline ME10 & $9.56 \times 10^{1}$ & n.a. & $9.80 \times 10^{-1}$ & n.a. & & & $9.83 \times 10^{1}$ \\
\hline ME25 & $7.97 \times 10^{1}$ & n.a. & 2.45 & n.a. & & & $8.38 \times 10^{1}$ \\
\hline ME50 & $5.31 \times 10^{1}$ & n.a. & 4.90 & n.a. & 1.64 & $1.48 \times 10^{-2}$ & $5.97 \times 10^{1}$ \\
\hline MET10 & $9.57 \times 10^{1}$ & n.a. & 1.03 & 6.17 & & & $1.05 \times 10^{2}$ \\
\hline MET25 & $7.97 \times 10^{1}$ & n.a. & 2.59 & $1.56 \times 10^{1}$ & & & $9.95 \times 10^{1}$ \\
\hline MET50 & $5.31 \times 10^{1}$ & n.a. & 5.18 & $3.12 \times 10^{1}$ & & & $9.11 \times 10^{1}$ \\
\hline
\end{tabular}

ED—Electrodialytic Treatment; TT—Thermal Treatment; GWP—Global Warming Potential; and n.a.—not applicable. 
Table A3. Environmental impacts in the Ozone Depletion Potential category, from the production of $1 \mathrm{t}$ of mortars with cement and treated mining residues as binder constituents.

\begin{tabular}{lccccc}
\hline \multirow{2}{*}{ Mortar } & \multicolumn{3}{c}{ ODP (kg CFC-11 eq.) } \\
\cline { 2 - 6 } & Cement & $\begin{array}{c}\text { Disposal of } \\
\text { Mining Residues }\end{array}$ & $\begin{array}{c}\text { ED Mining } \\
\text { Residues }\end{array}$ & $\begin{array}{c}\text { TT Mining } \\
\text { Residues }\end{array}$ & Tand \\
REF & $1.58 \times 10^{-8}$ & $1.41 \times 10^{-5}$ & n.a. & n.a. & n.a. \\
ME10 & $1.43 \times 10^{-8}$ & n.a. & $5.74 \times 10^{-8}$ & n.a. & $2.55 \times 10^{-7}$ \\
ME25 & $1.19 \times 10^{-8}$ & n.a. & $1.44 \times 10^{-7}$ & n.a. & $6.59 \times 10^{-10}$ \\
ME50 & $7.92 \times 10^{-9}$ & n.a. & $2.87 \times 10^{-7}$ & $5.11 \times 10^{-7}$ \\
MET10 & $1.43 \times 10^{-8}$ & n.a. & $6.01 \times 10^{-8}$ & $5.84 \times 10^{-7}$ & $5.1 \times 10^{-7}$ \\
MET25 & $1.19 \times 10^{-8}$ & n.a. & $1.52 \times 10^{-7}$ & $1.47 \times 10^{-6}$ & \\
MET50 & $7.92 \times 10^{-9}$ & n.a. & $3.03 \times 10^{-7}$ & $2.95 \times 10^{-6}$ & \\
\hline
\end{tabular}

ED—Electrodialytic Treatment; TT—Thermal Treatment; ODP—Ozone depletion Potential; and n.a.—not applicable.

Table A4. Environmental impacts in the Photochemical Ozone Creation Potential category, from the production of $1 \mathrm{t}$ of mortars with cement and treated mining residues as binder constituents.

\begin{tabular}{lccccc}
\hline \multirow{2}{*}{ Mortar } & \multicolumn{3}{c}{ POCP (kg Ethene eq.) } \\
\cline { 2 - 6 } & Cement & $\begin{array}{c}\text { Disposal of } \\
\text { Mining Residues }\end{array}$ & $\begin{array}{c}\text { ED Mining } \\
\text { Residues }\end{array}$ & $\begin{array}{c}\text { TT Mining } \\
\text { Residues }\end{array}$ & Sand \\
REF & $1.68 \times 10^{-2}$ & 2.30 & n.a. & n.a. & 2.32 \\
ME10 & $1.52 \times 10^{-2}$ & n.a. & $2.10 \times 10^{-3}$ & n.a. & $7.20 \times 10^{-4}$ \\
ME25 & $1.26 \times 10^{-2}$ & n.a. & $5.25 \times 10^{-3}$ & n.a. & $4.30 \times 10^{-6}$ \\
ME50 & $8.42 \times 10^{-3}$ & n.a. & $1.05 \times 10^{-2}$ & n.a. & $1.80 \times 10^{-2}$ \\
MET10 & $1.52 \times 10^{-2}$ & n.a. & $2.20 \times 10^{-3}$ & $7.63 \times 10^{-4}$ & $1.96 \times 10^{-2}$ \\
MET25 & $1.26 \times 10^{-2}$ & n.a. & $5.55 \times 10^{-3}$ & $1.92 \times 10^{-3}$ & $1.89 \times 10^{-2}$ \\
MET50 & $8.42 \times 10^{-3}$ & n.a. & $1.11 \times 10^{-2}$ & $3.85 \times 10^{-3}$ & $2.08 \times 10^{-2}$ \\
\hline
\end{tabular}

ED—Electrodialytic Treatment; TT—Thermal Treatment; POCP—Photochemical Ozone Creation Potential; and n.a—not applicable.

Table A5. Environmental impacts in the Acidification Potential category, from the production of $1 \mathrm{t}$ of mortars with cement and treated mining residues as binder constituents.

\begin{tabular}{|c|c|c|c|c|c|c|c|}
\hline \multirow[b]{2}{*}{ Mortar } & \multicolumn{7}{|c|}{$\mathrm{AP}\left(\mathrm{kg} \mathrm{SO} \mathrm{S}_{2}\right.$ eq.) } \\
\hline & Cement & $\begin{array}{c}\text { Disposal of } \\
\text { Mining Residues }\end{array}$ & $\begin{array}{l}\text { ED Mining } \\
\text { Residues }\end{array}$ & $\begin{array}{l}\text { TT Mining } \\
\text { Residues }\end{array}$ & Sand & Water & Total \\
\hline REF & $1.74 \times 10^{-1}$ & 1.73 & n.a. & n.a. & & & 1.91 \\
\hline ME10 & $1.57 \times 10^{-1}$ & n.a. & $3.92 \times 10^{-3}$ & n.a. & & & $1.73 \times 10^{-1}$ \\
\hline ME25 & $1.31 \times 10^{-1}$ & n.a. & $9.80 \times 10^{-3}$ & n.a. & & & $1.53 \times 10^{-1}$ \\
\hline ME50 & $8.71 \times 10^{-2}$ & n.a. & $1.96 \times 10^{-2}$ & n.a. & $1.27 \times 10^{-2}$ & $1.08 \times 10^{-4}$ & $1.19 \times 10^{-1}$ \\
\hline MET10 & $1.57 \times 10^{-1}$ & n.a. & $4.11 \times 10^{-3}$ & $1.51 \times 10^{-2}$ & & & $1.89 \times 10^{-1}$ \\
\hline MET25 & $1.31 \times 10^{-1}$ & n.a. & $1.04 \times 10^{-2}$ & $3.81 \times 10^{-2}$ & & & $1.92 \times 10^{-1}$ \\
\hline MET50 & $8.71 \times 10^{-2}$ & n.a. & $2.07 \times 10^{-2}$ & $7.62 \times 10^{-2}$ & & & $1.97 \times 10^{-1}$ \\
\hline
\end{tabular}

ED—Electrodialytic Treatment; TT—Thermal Treatment; AP—Acidification Potential; and n.a.—not applicable.

Table A6. Environmental impacts in the Eutrophication Potential category, from the production of $1 \mathrm{t}$ of mortars with cement and treated mining residues as binder constituents.

\begin{tabular}{|c|c|c|c|c|c|c|c|}
\hline \multirow[b]{2}{*}{ Mortar } & \multicolumn{7}{|c|}{$\mathrm{EP}\left(\mathrm{kg} \mathrm{PO}_{4}{ }^{3-}\right.$ eq.) } \\
\hline & Cement & $\begin{array}{c}\text { Disposal of } \\
\text { Mining Residues }\end{array}$ & $\begin{array}{l}\text { ED Mining } \\
\text { Residues }\end{array}$ & $\begin{array}{l}\text { TT Mining } \\
\text { Residues }\end{array}$ & Sand & Water & Total \\
\hline REF & $2.50 \times 10^{-2}$ & $1.58 \times 10^{-2}$ & n.a. & n.a. & & & $4.22 \times 10^{-2}$ \\
\hline ME10 & $2.25 \times 10^{-2}$ & n.a. & $1.96 \times 10^{-4}$ & n.a. & & & $2.41 \times 10^{-2}$ \\
\hline ME25 & $1.88 \times 10^{-2}$ & n.a. & $4.90 \times 10^{-4}$ & n.a. & & & $2.06 \times 10^{-2}$ \\
\hline ME50 & $1.25 \times 10^{-2}$ & n.a. & $9.80 \times 10^{-4}$ & n.a. & $1.35 \times 10^{-3}$ & $5.54 \times 10^{-6}$ & $1.49 \times 10^{-2}$ \\
\hline MET10 & $2.26 \times 10^{-2}$ & n.a. & $2.05 \times 10^{-4}$ & $9.49 \times 10^{-4}$ & & & $2.51 \times 10^{-2}$ \\
\hline MET25 & $1.88 \times 10^{-2}$ & n.a. & $5.18 \times 10^{-4}$ & $2.39 \times 10^{-3}$ & & & $2.31 \times 10^{-2}$ \\
\hline MET50 & $1.25 \times 10^{-2}$ & n.a. & $1.04 \times 10^{-3}$ & $4.79 \times 10^{-3}$ & & & $1.97 \times 10^{-2}$ \\
\hline
\end{tabular}

ED—Electrodialytic treatment; TT—Thermal treatment; EP—Eutrophication Potential; and n.a.—not applicable. 


\section{References}

1. Global Status Report for Buildings and Construction: Towards a Zero-Emission, Efficient and Resilient Buildings and Construction Sector; United Nations Environment Programme: Nairobi, Kenya, 2020.

2. Going Climate-Neutral by 2050-A Strategic Long Term Vision for a Prosperous, Modern, Competitive and Climate-Neutral EU; European Commission: Brussels, Belgium, 2019.

3. Communication from The Commission to The European Parliament, The European Council, The Council, The European Economic and Social Committee and The Committee of the Regions-The European Green Deal; Com/2019/640 Final; European Commission: Brussels, Belgium, 2019.

4. Mancini, L.; Vidal-Legaz, B.; Vizzarri, M.; Wittmer, D.; Grassi, G.; Pennington, D.W. Mapping the Role of Raw Materials in Sustainable Development Goals. In Sustainable Development Goals. A Preliminary Analysis of Links, Monitoring Indicators, and Related Policy Initiatives; Publications Office of the European Union: Luxembourg, 2019.

5. Candeias, C.; Ávila, P.F.; Silva, E.F.; Ferreira, A.; Salgueiro, A.R.; Teixeira, J.P. Acid mine drainage from the Panasqueira mine and its influence on Zêzere river (Central Portugal). J. Afr. Earth Sci. 2014, 99, 705-712. [CrossRef]

6. Environmental Law Alliance Worldwide Guidebook for Evaluating Mining Project EIAs, 1st ed.; Environmental Law Alliance Worldwide: Eugene, OR, USA, 2010.

7. Candeias, C.; Melo, R.; Ávila, P.F.; Ferreira da Silva, E.; Salgueiro, A.R.; Teixeira, J.P. Heavy metal pollution in mine-soil-plant system in S. Francisco de Assis-Panasqueira mine (Portugal). Appl. Geochem. 2014, 44, 12-26. [CrossRef]

8. Csavina, J.; Field, J.; Taylor, M.P.; Gao, S.; Landázuri, A.; Betterton, E.A.; Sáez, A.E. A review on the importance of metals and metalloids in atmospheric dust and aerosol from mining operations. Sci. Total Environ. 2012, 433, 58-73. [CrossRef] [PubMed]

9. Gou, M.; Zhou, L.; Then, N.W.Y. Utilization of tailings in cement and concrete: A review. Sci. Eng. Compos. Mater. 2019, 26, 449-464. [CrossRef]

10. Ahmari, S.; Ren, X.; Toufigh, V.; Zhang, L. Production of geopolymeric binder from blended waste concrete powder and fly ash. Constr. Build. Mater. 2012, 35, 718-729. [CrossRef]

11. Sangiorgi, C.; Lantieri, C.; Tataranni, P.; Castro-Gomes, J.; Gabriel, M. Reuse of mining waste into innovative alkali-activatedbased materials for road pavement applications. In Proceedings of the 4th International Chinese European Workshop (CEW)Functional Pavement Design, Delft, The Netherlands, 29 June-1 July 2016; pp. 1745-1753.

12. Sedira, N.; Castro-Gomes, J.; Magrinho, M. Red clay brick and tungsten mining waste-based alkali-activated binder: Microstructural and mechanical properties. Constr. Build. Mater. 2018, 190, 1034-1048. [CrossRef]

13. Kastiukas, G.; Zhou, X.; Wan, K.T.; Castro Gomes, J. Lightweight alkali-activated material from mining and glass waste by chemical and physical foaming. J. Mater. Civ. Eng. 2019, 31, 04018397. [CrossRef]

14. Pacheco-Torgal, F.; Castro-Gomes, J.P.; Jalali, S. Adhesion characterization of tungsten mine waste geopolymeric binder: Influence of OPC concrete substrate surface treatment. Constr. Build. Mater. 2008, 22, 154-161. [CrossRef]

15. Choi, Y.W.; Kim, Y.J.; Choi, O.; Lee, K.M.; Lachemi, M. Utilization of tailings from tungsten mine waste as a substitution material for cement. Constr. Build. Mater. 2009, 23, 2481-2486. [CrossRef]

16. Kirkelund, G.M.; Magro, C.; Guedes, P.; Jensen, P.E.; Ribeiro, A.B.; Ottosen, L.M. Electrodialytic removal of heavy metals and chloride from municipal solid waste incineration fly ash and air pollution control residue in suspension-Test of a new two compartment experimental cell. Electrochim. Acta 2015, 181, 73-81. [CrossRef]

17. Ribeiro, A.B.; Rodríguez-Maroto, J.M. Electroremediation of Heavy Metal-Contaminated Soils—Processes and Applications. In Trace Elements in the Environment: Biogeochemistry, Biotechnology, and Bioremediation; Prasad, M.N.V., Sajwan, K.S., Naidu, R., Eds.; CRC Press: Boca Raton, FL, USA, 2006; pp. 341-368.

18. Heath, A.; Paine, K.; McManus, M. Minimising the global warming potential of clay based geopolymers. J. Clean. Prod. 2014, 78, 75-83. [CrossRef]

19. Almeida, J.; Santos Silva, A.; Faria, P.; Ribeiro, A.B. Assessment on tungsten mining residues potential as partial cement replacement. KnE Eng. 2020, 5, 228-237.

20. Almeida, J.; Faria, P.; Ribeiro, A.B.; Santos Silva, A. Cement-based mortars production applying mining residues treated with an electro-based technology and a thermal treatment: Technical and economic effects. Constr. Build. Mater. 2021, $280,122483$. [CrossRef]

21. Santos, T.; Almeida, J.; Silvestre, J.; Faria, P. Life cycle assessment of mortars: A review on technical potential and drawbacks. Constr. Build. Mater. 2021, 288, 123069. [CrossRef]

22. Ruan, S.; Unluer, C. Influence of supplementary cementitious materials on the performance and environmental impacts of reactive magnesia cement concrete. J. Clean. Prod. 2017, 159, 62-73. [CrossRef]

23. ISO 14040: Environmental Management, Life Cycle Assessment, Principles and Framework; International Standard Organization: Geneva, Switzerland, 2006.

24. ISO 14044: Environmental Management, Life Cycle Assessment, Requirements and Guidelines; International Standard Organization: Geneva, Switzerland, 2006.

25. EN 15804: 2012 + A2: 2019—Sustainability of Construction Works_Environmental Product Declarations-Core Rules for the Product Category of Construction Products; European Committee for Standardization: Brussels, Belgium, 2012.

26. Farinha, C.B.; Silvestre, J.D.; de Brito, J.; Veiga, M.R. Life cycle assessment of mortars with incorporation of industrial wastes. Fibers 2019, 7, 59. [CrossRef] 
27. Almeida, J.; Faria, P.; Ribeiro, A.B.; Silva, A.S. Effect of mining residues treated with an electrodialytic technology on cement-based mortars. Clean. Eng. Technol. 2020, 1, 100001. [CrossRef]

28. EN 197-1: 2011-Cement: Part 1: Composition, Specifications and Conformity Criteria for Common Cements; European Committee for Standardization: Brussels, Belgium, 2011.

29. EN 196-1: 2017-Methods of Testing Cement: Part 1: Determination of Strength; European Committee for Standardization: Brussels, Belgium, 2017.

30. Acero, A.P.; Rodríguez, C.; Changelog, A.C. LCIA Methods Impact Assessment Methods in Life Cycle Assessment and Their Impact Categories; GreenDelta Icl.: Berlin, Germany, 2016.

31. Braga, A.M.; Silvestre, J.D.; de Brito, J. Compared environmental and economic impact from cradle to gate of concrete with natural and recycled coarse aggregates. J. Clean. Prod. 2017, 162, 529-543. [CrossRef]

32. Van Oers, L.; Koning, A.; Guinée, J.B.; Huppes, G. Abiotic Resource Depletion in Lca-Improving Characterisation Factors for Abiotic Resource Depletion as Recommended in The New Dutch Lca Handbook; Road and Hydraulic Engineering Institute: Amsterdam, The Netherlands, 2002.

33. Furberg, A.; Arvidsson, R.; Molander, S. Environmental life cycle assessment of cemented carbide (WC-Co) production. J. Clean. Prod. 2019, 209, 1126-1138. [CrossRef]

34. Franco, A.; Vieira, R.; Bunting, R. The Panasqueira Mine at a Glance; International Tungsten Industry Association Newsletter: London, UK, 2014; Volume 3.

35. Song, X.; Pettersen, J.B.; Pedersen, K.B.; Røberg, S. Comparative life cycle assessment of tailings management and energy scenarios for a copper ore mine: A case study in Northern Norway. J. Clean. Prod. 2017, 164, 892-904. [CrossRef]

36. Sousa, S.; Silva, A.S.; Velosa, A.; Gameiro, A.; Rocha, F. Mitigation of internal expansive reaction: The role of tungsten mine sludge. Mater. Sci. Forum 2013, 730-732, 468-473. [CrossRef]

37. Burchart-Korol, D.; Kruczek, M. Depletion of abiotic resources in the steel production in Poland. Metalurgija 2016, 55, 531-534.

38. United States Environmental Protection Agency Greenhouse Gas Emissions-Understanding Global Warming Potentials. Available online: https://www.epa.gov/ghgemissions/understanding-global-warming-potentials (accessed on 15 March 2021).

39. Zajac, M.; Bolte, G.; Skocek, J.; Ben Haha, M. Modelling the effect of the cement components fineness on performance and environmental impact of composite cements. Constr. Build. Mater. 2021, 276, 122108. [CrossRef]

40. Coimbra, K.T.O.; Alcântara, E.; de Souza Filho, C.R. Satellite evidence for pervasive water eutrophication in the Doce River reservoirs following the collapse of the Fundao dam in Brazil. Environ. Pollut. 2021, 272, 116014. [CrossRef]

41. Jermakka, J.; Wendling, L.; Sohlberg, E.; Heinonen, H.; Merta, E.; Laine-Ylijoki, J.; Kaartinen, T.; Mroueh, U.-M. Nitrogen Compounds at Mines and Quarries: Sources, Behaviour and Removal from Mine and Quarry Waters_Literature Study; VTT Technical Research Centre of Finland: Tampere, Finland, 2015.

42. Ojovan, M.I.; Lee, W.E.; Kalmykov, S.N. Immobilisation of Radioactive Waste in Cement. In An Introduction to Nuclear Waste Immobilisation; Elsevier: London, UK, 2019; pp. 271-303.

43. Heijungs, R.; Guinée, J.; Huppes, G.; Lankreijer, R.; Udo de Haes, H.; Wegener Sleeswijk, A.; Ansems, A.; Eggels, P.; Duin, R.; Goede, H. Environmental Life Cycle Assessment of Products; CML: Leiden, The Netherlands, 1992.

44. Haagen-Smit, A.J.; Bradley, C.E.; Fox, M.M. Ozone formation in photochemical oxidation of organic substances. Ind. Eng. Chem. 1953, 45, 2086-2089. [CrossRef]

45. Dincer, I.; Abu-Rayash, A. Sustainability Modeling. In Energy Sustainability; Elsevier: London, UK, $2020 ;$ pp. 119-164.

46. Voicu, G.; Ciobanu, C.; Istrate, I.A.; Tudor, P. Emissions control of hydrochloric and fluorhydric acid in cement factories from Romania. Int. J. Environ. Res. Public Health 2020, 17, 1019. [CrossRef]

47. Kim, T.; Tae, S.; Chae, C. Analysis of environmental impact for concrete using LCA by varying the recycling components, the compressive strength and the admixture material mixing. Sustainability 2016, 8, 389. [CrossRef]

48. Spooren, J.; Binnemans, K.; Björkmalm, J.; Breemersch, K.; Dams, Y.; Folens, K.; González-Moya, M.; Horckmans, L.; Komnitsas, K.; Kurylak, W.; et al. Near-zero-waste processing of low-grade, complex primary ores and secondary raw materials in Europe: Technology development trends. Resour. Conserv. Recycl. 2020, 160, 104919. [CrossRef]

49. Critical Raw Materials Resilience: Charting a Path towards Greater Security and Sustainability; COM/2020/474 Final; European Commission: Brussels, Belgium, 2020.

50. Almeida, J.; Magro, C.; Mateus, E.P.; Ribeiro, A.B. Electrodialytic hydrogen production and critical raw materials recovery from secondary resources. Water 2020, 12, 1262. [CrossRef]

51. Villen-Guzman, M.; Paz-Garcia, J.M.; Rodriguez-Maroto, J.M.; Gomez-Lahoz, C.; Garcia-Herruzo, F. Acid enhanced electrokinetic remediation of a contaminated soil using constant current density: Strong vs. weak acid. Sep. Sci. Technol. 2014, 49, 1461-1468. [CrossRef]

52. Santos, T.; Nunes, L.; Faria, P. Production of eco-efficient earth-based plasters: Influence of composition on physical performance and bio-susceptibility. J. Clean. Prod. 2017, 167, 55-67. [CrossRef]

53. Zheng, X.; Huang, G.; Li, J.; Liu, L.; Zhang, X.; Pan, X. Development of a factorial water policy simulation approach from production and consumption perspectives. Water Res. 2021, 193, 116892. [CrossRef] [PubMed]

54. Bederina, M.; Makhloufi, Z.; Bounoua, A.; Bouziani, T.; Quéneudec, M. Effect of partial and total replacement of siliceous river sand with limestone crushed sand on the durability of mortars exposed to chemical solutions. Constr. Build. Mater. 2013, 47, 146-158. [CrossRef] 
55. Ulsen, C.; Antoniassi, J.L.; Martins, I.M.; Kahn, H. High quality recycled sand from mixed CDW-Is that possible? J. Mater. Res. Technol. 2021, 12, 29-42. [CrossRef]

56. Grbeš, A. A life cycle assessment of silica sand: Comparing the beneficiation processes. Sustainability 2015, 8, 11. [CrossRef] 